\title{
Correlation of Microscopic and Automated Cell Counter Results of Newer Hematological Variables in Diagnosis and Recovery of Anemia
}

\author{
Ahuja Ankur'1, Pandey Pankaj², Gahlot Gaurav PS'*, Badwal Sonia ${ }^{3}$, Moond Saurabh, Dhanetwal Murari Lal ${ }^{5}$ \\ ${ }^{1}$ Dept of Lab \& Mol Med, Army Hospital (Research \&Referral) Delhi, India \\ ${ }^{2}$ Dept of Pathology, All India Institute of Medical Sciences, Rishikesh, Uttarankhand, India \\ ${ }^{3}$ Military Hospital Shimla, Himachal Pradesh, India \\ ${ }^{4}$ Dept of Pathology, Vardhman Mahavir Medical College \& Safdarjung Hospital, Delhi, India \\ ${ }_{5}^{5}$ Dept of Pathology, Jaipur National University Institute for Medical Sciences and Research Centre, Jaipur India
}

\begin{abstract}
Background: The correct interpretation of new hematological parameters generated by Automated Cell Counters (ACCs) requires extensive knowledge for the clinical significance of these results. The present study will enlighten the vital role of the traditional \& new parameters of the Complete Blood Count (CBC) in early diagnosis and follow up stage after treatment especially in the setting of anemia

Aims: To evaluate the vast \& extended utility of newer hematological parameters generated by ACCs beyond their conventional role of $\mathrm{CBC}$ and Differential Leukocyte Count (DLC)

Study Design: This is a cross sectional observational study of results obtained from blood samples of 100 patients having various types of anemia diagnosed over a period of 18 months

Subjects \& Methods: EDTA blood samples of the patient were collected under aseptic precautions and processed within 2 hours through new generation hematology analyzer i.e. ADVIAR 2120i. The peripheral blood film examination in each case was performed on LeishmanGeimsa stained smear. Second EDTA samples were taken on 2nd and 10th day of follow up of IDA and thalassemia cases respectively.

Statistical Analysis Used: The hematological, parameters obtained from ACCs/microscopic were assessed by Student's t-test, Fisher's exact test using the SPSS 21.0 software with considering $\mathrm{p}$ value $<0.05$ as significant

Results: IRF and reticulocyte\% can distinguish well between IDA and thalassemia major. $\mathrm{CHr}$ and $\mathrm{MCVr}$ are useful parameter for diagnosis of IDA/thalassemia and vitamin B12 deficiency anemia. CHr is the first parameter for monitoring response treatment of anemia.
\end{abstract}

Keywords: Automated Cell Counters, Iron Deficiency Anemia, Thalassemia, Reticulocyte Count, Immature Reticulocyte Fraction, Mean Reticulocyte Volume, Mean Reticulocyte Hemoglobin Content, Fragmented RBC Count

\section{Introduction}

Automated Cell Counters (ACCs) are indispensible in view of accuracy and efficacy, however the manual age old Complete Blood Count (CBC) methodology is not yet obsolete due to economic considerations and non availability of ACCs, particularly in the smaller laboratory set ups in developing countries.

CBC primarily includes Red Blood Cells (RBCs), Hemoglobin $(\mathrm{Hb})$ concentration, Mean Corpuscular Volume (MCV), White Blood Cells (WBCs), Platelet count etc which give rise to other parameters like Hematocrit (Hct), Mean Corpuscular Hemoglobin (MCH), Mean Corpuscular Hemoglobin Concentration (MCHC), and Red cell Distribution Width (RDW). First blood counts and its aid to clinical diagnosis was established by Professor Karl Vierordt in 1852. ${ }^{[2]}$ In 1896, George Oliver performed blood cells counting eye based measurement of light loss caused due to scattering and absorption in a test tube filled with diluted blood. This method could be considered the forerunner of automated blood count. In 1940s, Wallace Coulter evolved a simplified blood cell analysis tool for rapid screening of large number of blood samples. ${ }^{[7]}$ Modern automated hematology technology works either on optical method (light scatter) or impedance Coulter method (changes in electrical current induced by blood cells flowing through an electrically charged opening) or a combination of both. Progressive improvement in these instruments led enumeration and evaluation of blood cells with great accuracy, precision, speed at low cost.

ACCs are available as three to seven-part differential systems which can count neutrophils, eosinophils, basophils, lymphocytes, monocytes large unstained cells (atypical lymphocytes) and large immature cells (blasts \& immature granulocytes) based on its configuration. Inherent flagging systems, in built quality control programs and automated maintenance are additional qualities of ACCs. 
The newer ACCs like Advia $^{\mathrm{R}} 2120 \mathrm{i}$ and Sysmex XT4000i provide parameters like Nucleated Red Blood Cells (NRBCs), Immature Reticulocyte Fraction (IRF), Mean Reticulocyte Volume (MCVr) and Mean Reticulocyte Hemoglobin Content (CHr), Fragmented RBCs count (FRBCs) and Immature Platelet Fraction (IPF). [Table 1] We will discuss the salient features of some of the most useful new parameters.

Nucleated Red Blood Cells are primarily produced and stored in bone marrow (BM) in response to erythropoietin as precursors to reticulocytes and mature erythrocytes. Usually NRBCs are found only in the circulation of fetuses and newborn infants upto $3^{\text {rd }}$ or $4^{\text {th }}$ day of life. Their presence in an adult's peripheral blood smear (PBS) is pathogenic and reflects very high demand for $\mathrm{BM}$ to produce $\mathrm{RBCs}$ leading to release of immature RBCs into circulation. NRBCs count may help in differential diagnosis of anemia and to determine transfusion needs. The reference value of mean NRBC by manual PBS is $0 / 100 \mathrm{WBC}$ and by $\mathrm{Advia}^{\mathrm{R}} 2120 \mathrm{i}$ range is $0-0.2 \times 10^{3}$ cells/cumm respectively. As NRBC has size similar to lymphocytes, many hematology analyzers misclassify them and may generate wrong total leukocyte and lymphocyte counts. Usually such samples are flagged by ACCs indicating the need to get corrected WBC count by microscopic analysis as; Corrected $\mathrm{WBC}=$ Total $\mathrm{WBC}$ $x[100 \div(\mathrm{NRBC}+100)]$

A schistocyte is an irregular, jagged, fragmented portion of $\mathrm{RBC}$; formed due to mechanical destruction as in hemolytic anemia, mechanical artificial heart valves, hemolytic uremic syndrome, thrombotic thrombocytopenic purpura, Microangiopathic Hemolytic Anemia (MAHA), disseminated intravascular coagulation (DIC) and aortic stenosis. Owing to the abnormal shape, schistocyte easily undergoes hemolysis or get removed by macrophages in the spleen. ${ }^{[73]}$ The reference value of schistocytes on microscopy is $<2$ schistocytes at 100x magnification and mean fragmented RBCs (FRC) by $\mathrm{Advia}^{\mathrm{R}} 2120 \mathrm{i}$ is 0.01 $0.02 \mathrm{RBC}$ fragmentsx $10^{6}$ cells/ul. ${ }^{[168]}$ Overall the standard method for a schistocyte count remains microscopic examination of PBS. ${ }^{[80]}$

The reticulocyte is immature, non-nucleated newly produced $\mathrm{RBC}$ that contains at least 2 granules of reticulum. Reticulocyte count in blood reflects the effective erythropoiesis. ${ }^{[87]}$ In healthy individuals, reticulocytes circulate in the peripheral blood for 1-2 days after being released from BM. At times of increased erythropoietic demand, their life span in peripheral blood increases to $>3$ days due to premature release of immature/stress reticulocytes from the BM. This Immature Reticulocyte Fraction (IRF) is the quantitative proportion of all immature/younger reticulocytes and is calculated as a ratio of immature reticulocytes to the total number of reticulocytes. IRF is a very early and sensitive index of marrow erythropoietic activity and its fraction in excess of $5 \%$ is a reliable marker for hemopoietic recovery. ${ }^{[81]}$ IRF value along with reticulocyte count can be utilized to differentiate various causes of anemia [Table 1].

Reticulocyte Production Index (RPI) give a snapshot of the functional iron available for incorporation into hemoglobin within RBCs over the previous 3-4 days. A decreased value generally reflects reduced cellular hemoglobin content and is the strongest predictor of IDA in children. ${ }^{[131]}$

Determination of mean reticulocyte hemoglobin content $(\mathrm{CHr})$ provides an early measure of functional iron deficiency in adults and children because reticulocytes are the earliest erythrocytes released into blood and circulate for $1-2$ days. ${ }^{[138]} \mathrm{CHr}$ value can be used as an early measure of the response to iron therapy, increasing within 2-4 days of the initiation of intravenous iron therapy. Various other biochemical parameters used to diagnose IDA include serum ferritin, transferrin saturation, total iron binding capacity and serum iron however are affected by many factors.

Mean Reticulocyte Volume (MCVr) is a specific new index that has potential to screen hereditary spherocytosis and to differentiate hemolytic anemia with megaloblastic anemia.

Table1: Correlation of IRF with Absolute Reticulocyte Count \& Clinical Conditions.

\begin{tabular}{|l|l|l|}
\hline IRF & Absolute reticulocyte count & Clinical conditions \\
\hline Low & Low & Aplastic anemia, chronic renal failure \\
\hline High & Low & Repopulating bone marrow \\
\hline Low to normal & Low & Early erythropoietic response after anemia or engraftment after BMT \\
\hline High & High & $\begin{array}{l}\text { Response to erythropoietin treatment or early acute hemorrhage or } \\
\text { hemolytic anemia }\end{array}$ \\
\hline High & Low to normal & Early response to iron therapy \\
\hline
\end{tabular}


Table 2: Clinical Correlation of Old \& New Hematological Parameters in Anemia.

\begin{tabular}{|c|c|c|c|}
\hline $\begin{array}{l}\text { Parameter OLD RBC } \\
\text { PARAMETER }\end{array}$ & Availability & $\begin{array}{l}\text { Proposed clinical } \\
\text { applications }\end{array}$ & Limitations \\
\hline $\begin{array}{l}\text { Mean Corpuscular volume } \\
(\mathrm{MCV})(\mathrm{fL})^{[92,93]}\end{array}$ & All analyzers & $\begin{array}{l}\text { Anemia classification based } \\
\text { on morphological approach }\end{array}$ & $\begin{array}{l}\text { Affected by preanalytical variables } \\
\text { (storage, temperature, time) }\end{array}$ \\
\hline $\begin{array}{l}\text { Mean corpuscular } \\
\text { Hemoglobin }(\mathrm{MCH})(\mathrm{pg})^{[94,95]}\end{array}$ & All analyzers & $\begin{array}{l}\text { Useful when hemoglobin } \\
\text { synthesis is impaired as in } \\
\text { iron deficiency anemia }\end{array}$ & Highly correlated with MCV \\
\hline $\begin{array}{l}\text { Mean Corpuscular } \\
\text { Hemoglobin Concentration } \\
(\mathrm{MCHC})(\mathrm{g} / \mathrm{L})^{[96,97]}\end{array}$ & All analyzers & $\begin{array}{l}\text { Increased in spherocytosis } \\
\text { due to reduced surface/ } \\
\text { volume ratio }\end{array}$ & $\begin{array}{l}\text { With some impedance analyzers, } \\
\text { the value is clamped around the } \\
\text { mean }\end{array}$ \\
\hline $\begin{array}{l}\text { Red cell Distribution Width } \\
\text { (RDW) (\%) }{ }^{[98-101]}\end{array}$ & All analyzers & $\begin{array}{l}\text { Generic marker of abnormality } \\
\text { when increased }\end{array}$ & $\begin{array}{l}\text { Of little usefulness in the } \\
\text { differential diagnosis of anemia. } \\
\text { Reference intervals are method } \\
\text { dependent }\end{array}$ \\
\hline \multicolumn{4}{|l|}{ NEW RBC PARAMETERS } \\
\hline $\begin{array}{l}\text { Percentage of hypochromic } \\
\text { red cells }{ }^{[102-105]}\end{array}$ & $\begin{array}{l}\text { Hypo\% (Siemens } \\
\text { Advia 2120) }\end{array}$ & $\begin{array}{l}\text { Assessment of iron availability } \\
\text { (absolute or functional) for } \\
\text { erythropoiesis based on iron } \\
\text { status in last } 3 \text { months }\end{array}$ & $\begin{array}{l}\text { Affected by preanalytical } \\
\text { variables (storage, temperature, } \\
\text { time) }\end{array}$ \\
\hline Parameter & Availability & Proposed clinical applications & Limitations \\
\hline $\begin{array}{l}\text { Percentage of hyperchromic } \\
\text { red cells }{ }^{[106,107]}\end{array}$ & $\begin{array}{l}\text { Hyper\% (Siemens } \\
\text { Advia 2120) }\end{array}$ & $\begin{array}{l}\text { Diagnosis of hereditary/ } \\
\text { immune spherocytosis }\end{array}$ & $\begin{array}{l}\text { Reference intervals and } \\
\text { diagnostic thresholds are method } \\
\text { dependent }\end{array}$ \\
\hline $\begin{array}{l}\text { Percentage of microcytic } \\
\text { red cells }{ }^{[108-111]}\end{array}$ & $\begin{array}{l}\text { Micro\% (Siemens } \\
\text { Advia 2120); \% } \\
\text { micro-R (Sysmex XE/ } \\
\text { XN) }\end{array}$ & $\begin{array}{l}\text { Useful in Combination with } \\
\text { other RBC Parameters } \\
\text { (mainly hypochromic } \\
\text { erythrocytes) to } \\
\text { obtain discriminant indices for } \\
\text { the differential diagnosis of } \\
\text { microcytic anemia }\end{array}$ & $\begin{array}{l}\text { Reference intervals and } \\
\text { diagnostic thresholds are method } \\
\text { dependent }\end{array}$ \\
\hline \multicolumn{4}{|l|}{$\begin{array}{l}\text { RETICULOCYTE } \\
\text { PARAMETERS }\end{array}$} \\
\hline $\begin{array}{l}\text { Immature, reticulocyte } \\
\text { fraction (IRF) }\end{array}$ & All analyzers & $\begin{array}{l}\text { Classification of anemias and } \\
\text { monitoring of treatment. Verify } \\
\text { aplastic anemia }\end{array}$ & $\begin{array}{l}\text { Reference intervals and } \\
\text { diagnostic cutoff are method } \\
\text { dependent }\end{array}$ \\
\hline $\begin{array}{l}\text { Reticulocyte mean } \\
\text { hemoglobin content (pg) } \\
\text { [122-125] }\end{array}$ & $\begin{array}{l}\text { CHr (Siemens Advia } \\
\text { 2120); Ret- He } \\
\text { (Sysmex XE/XN) }\end{array}$ & $\begin{array}{l}\text { Diagnosis of iron-deficient } \\
\text { erythropoiesis. Early } \\
\text { monitoring the response to } \\
\text { iron therapies }\end{array}$ & $\begin{array}{l}\text { Limited value in the presence of } \alpha \\
\text { or } \beta \text { thalassemia }\end{array}$ \\
\hline $\begin{array}{l}\text { Mean reticulocyte volume } \\
(\mathrm{fL})^{[121,124,126]}\end{array}$ & $\begin{array}{l}\text { MCVr (Siemens } \\
\text { Advia 2120) }\end{array}$ & $\begin{array}{l}\text { Diagnosis of iron-deficient } \\
\text { erythropoiesis. Early } \\
\text { monitoring of treatment with } \\
\text { B12/folate/iron in nutritional } \\
\text { anemia }\end{array}$ & $\begin{array}{l}\text { Affected by preanalytical Variables } \\
\text { (storage temperature, time) } \\
\text { Reference intervals strictly } \\
\text { method dependent }\end{array}$ \\
\hline
\end{tabular}


Table 3: Various Hematological Parameters in Anemia.

\begin{tabular}{|c|c|c|c|c|c|}
\hline Parameters & Control (50) & $\begin{array}{l}\text { IDA } \\
(45)\end{array}$ & $\begin{array}{c}\text { Megaloblastic } \\
\text { Anemia (45) }\end{array}$ & $\begin{array}{l}\text { CKD } \\
(40)\end{array}$ & Thalassemia (10) \\
\hline $\operatorname{MCV}(f l)$ & $85.2 \pm 4.6$ & $71.3 \pm 48$ & $110.4 \pm 8.2$ & $82.9 \pm 6.1$ & $67.8 \pm 4.1$ \\
\hline $\operatorname{MCVr}(\mathrm{fl})$ & $99.1 \pm 6.2$ & $90.5 \pm 5.4$ & $139.6 \pm 9.7$ & $98.6 \pm 4.3$ & $87.2 \pm 6$ \\
\hline MCVr/MCV ratio & 1.12 & 1.26 & 1.26 & 1.18 & 1.28 \\
\hline CHCM (g/dl) & $40.2 \pm 1.9$ & $29.4 \pm 2.1$ & $34 \pm 2.1$ & $29.9 \pm 2.4$ & $31.6 \pm 1.1$ \\
\hline $\mathrm{CHCMr}(\mathrm{g} / \mathrm{dl})$ & $31.7 \pm 1.4$ & $23.4 \pm 3.2$ & $26.1 \pm 2.9$ & $23.7 \pm 2.2$ & $24.4 \pm 1.6$ \\
\hline $\mathrm{CHCMr} / \mathrm{CHCM}$ ratio & 0.79 & 0.79 & 0.77 & 0.79 & 0.77 \\
\hline $\mathrm{CH}(\mathrm{pg})$ & $30.3 \pm 1.8$ & $20.5 \pm 1.6$ & $35.4+4.1$ & $22.7 \pm 2.1$ & $21.1 \pm 1.4$ \\
\hline $\mathrm{CHr}(\mathrm{pg})$ & $32.4 \pm 1.7$ & $21.1 \pm 1.7^{*}$ & $37.1 \pm 1.6^{*}$ & $24.8 \pm 1.6$ & $21.7 \pm 1.7^{*}$ \\
\hline $\mathrm{CH} / \mathrm{CHr}$ ratio & 0.93 & 0.98 & 0.95 & 0.91 & 0.97 \\
\hline Reticulocyte\% & $1.19 \pm 0.15$ & $0.34 \pm 0.06$ & $0.34 \pm 0.07$ & $0.66 \pm 0.08$ & $1 \pm 0.15$ \\
\hline IRF & $5.2 \pm 0.6$ & $0.62 \pm 0.18^{* *}$ & $0.66 \pm 0.19$ & $0.74 \pm 0.20$ & $2.9 \pm 0.5^{* *}$ \\
\hline
\end{tabular}

\section{Materials \& Methods}

This cross sectional observational prospective study was conducted in the Department of Laboratory Sciences $\&$ and Molecular Medicine at a "Tertiary Care SuperSpeciality Hospital" from Oct 2015 to Mar 2017 and included 100 and 10 cases of anemia and thalassemia respectively; to analyze different conventional and newer hematological parameters. The relevant clinical data was accrued from the data register in the blood collection centre/wards/concerned departments or by direct patient interaction. Pregnant women were not included in the study as the results might interfere due to initiation of hematinics in them during early pregnancy. Blood samples of selected cases were collected under aseptic precautions in EDTA vacutainer and processed within 2 hours of collection through new generation hematology analyzer i.e. ADVIA $^{\mathrm{R}}$ 2120i. Leishman-Geimsa stained peripheral blood film examination was performed by two experienced technologists followed by confirmation by a hematopathologist.

Additional tests like reticulocyte count, cytochemical evaluation and $\mathrm{Hb}$ electrophoresis were resorted wherever needed. Second EDTA samples were taken on $2^{\text {nd }}$ and $10^{\text {th }}$ day of follow up in cases of IDA and thalassemia respectively. The association between hematological, morphological and clinical features were tested using Student's t-test for continuous variables and the chi-square test (or Fisher's exact test) for qualitative variables. All statistical analyses will performed using the SPSS 21.0 software considering $\mathrm{p}$ value $<0.05$ as significant.

\section{Results}

Total 110 patients comprising of 100 cases of anemia (IDA: 45, Megaloblastic: 45 MAHA: 10) and 10 cases of thalassemia were included in the index study. Table 2 summarizes hematologic findings and reticulocyte parameters in the normal controls, IDA, megaloblastic anemia group, chronic kidney disease and thalassemia major group.

All ten patients of thalassemia major had increased mean NRBC by manual peripheral blood smear ranged from 25 $\mathrm{NRBC} / 100 \mathrm{WBC}$ to $106 \mathrm{NRBC} / 100 \mathrm{WBC}$ and by $\mathrm{Advia}^{\mathrm{R}}$ $2120 \mathrm{i}$ value ranged from $1.21 \times 10^{3} /$ cumm to $6.1 \times 10^{3} /$ cumm. Statistically significant correlation for calculating NRBCs was observed between both the methods ( $p$ value $<0.05)$.

All ten 10 patients of MAHA found to have increased schistocytes by microscopy as $>2$ per $100 x$ magnification. Mean value of fragmented RBCs (FRC) provided by Advia $^{\mathrm{R}} 2120 \mathrm{i}$ was $1.33 \times 10^{6}$ cells/uL with control value of $0.045 \times 10^{6}$ cells $/ \mathrm{uL}$ and cut off value of $>0.02 \times 10^{6}$ cells/ $\mathrm{uL}$. Statistically significant correlation for measuring schistocytes was observed between both methods ( $p$ value $<.0 .05)$.

Reticulocyte $\%$ was significantly decreased in IDA $(0.34 \pm 0.06)$ followed by megaloblastic anemia $(0.34 \pm 0.07)$ whereas was near normal only in thalassemia $(1 \pm 0.15)$ as compared to control group value of $1.19 \pm 0.15$.

IRF was done in cases of nutritional anemia, follow up cases of nutritional anemia, anemia of chronic disease and thalassemia. In IDA and megaloblastic anemia follow up was done on $2^{\text {nd }}$ and $10^{\text {th }}$ day and in case of thalassemia IRF was done at the time of diagnosis. Cases with IDA, $\mathrm{ACD}$, megaloblastic anemia, with their respective posttreatment iron therapy, erythropoietin and vitamin $\mathrm{B}_{12}$ therapy showed increased IRF. Cases of thalassemia had 
decreased IRF value of $2.9 \pm 0.5$ as compared to control group value of $5.2+0.6$.

$\mathrm{CHr}$ value was lowest in IDA $(21.1 \pm 1.7 \mathrm{pg})$ as compared to thalassemia $(21.7 \pm 1.7 \mathrm{pg})$, megaloblastic anemia $(37.1 \pm 1.6 \mathrm{pg})$ and control group $(32.4 \pm 1.7 \mathrm{pg})$. CHr value of $<26.2 \mathrm{pg}$ favours IDA. CHr from the baseline value of $21 \mathrm{pg}$ rose upto normal value of $31 \mathrm{pg}$ within 2 days to $32 \mathrm{pg}$ on $28^{\text {th }}$ day post treatment in IDA, while IRF value returned in 10-14 days. $\mathrm{CHr}$ was the first parameter that responded to iron therapy even before MCV and IRF.

IDA \& thalassemia patients had lower MCV, CHCM, $\mathrm{CHCMr}, \mathrm{CH}, \mathrm{CHr}$ values as compared to healthy and vitamin $\mathrm{B} 12$ deficiency group. $\mathrm{CH} / \mathrm{CHr}$ ratio was maximally increased in IDA (0.98) followed by thalassemia (0.97), megaloblastic anemia (0.91) with control group value of 0.93 .

In megaloblastic anemia, vitamin B12 therapy results in increased reticulocyte $\%$ count and IRF and decreased $\mathrm{MCVr}, \mathrm{CHCMr}$ and $\mathrm{CHr}$ in 21 to 28 days. [Table 3]

\section{Discussion}

Greek word 'Anemia' means an=not, naime=blood i.e. not having blood and functionally defined as an insufficient RBCs mass to adequately deliver oxygen to peripheral tissues. World Health Organization defines the lower limit of normal $\mathrm{Hb}$ concentration at sea level to be $14.0 \mathrm{gm} / \mathrm{dl}$ in adult men and $12.0 \mathrm{gm} / \mathrm{dl}$ in adult women whereas in individuals of $>65$ years) to be $8.5 \mathrm{gm} / \mathrm{dl}$.

This study was performed to evaluate, analyze the clinical applications of traditional, microscopic results with newer hematological parameters generated by $\mathrm{ACC}$ and to explore their role in the course of diagnosis, hematological recoveries of IDA, thalassemia, ACD and megaloblastic anemia.

All ten patients of thalassemia major were analyzed for increased mean NRBC by microscopy and Advia ${ }^{\mathrm{R}} 2120 \mathrm{i}$. The correlation of our results between both methods was statistically significant ( $\mathrm{p}$ value $<0.05$ ) and corroborating well with other studies. ${ }^{[166,167]}$ As manual counting of $\mathrm{NRBC}$ is a time consuming process, so use of $\mathrm{Advia}^{\mathrm{R}} 2120 \mathrm{i}$ is recommended.

For fragmented RBCs, we included ten patients of MAHA. Value of FRCs by Advia ${ }^{\mathrm{R}} 2120 \mathrm{i}$ was significantly high in patients with raised schistocytes on microscopy ( $p$ value $<0.05$ ). Our result was in concordance with J-F Lesesve et al. ${ }^{[169,170]}$ So though both methods have depicted the schistocytes, however manual counting of schistocytes is a time consuming process, so $\mathrm{Advia}^{\mathrm{R}} 2120 \mathrm{i}$ can be used.
In anemia cases, the reticulocyte count is an indicator of effective erythropoiesis. The recent development of automated reticulocyte counts with the help of Advia $^{R}$ $2120 \mathrm{i}$ made it easy to calculate the proportion of IRF and permitted more precise counting of reticulocytes. Our results of IRF as sensitive index of marrow erythropoietic activity are similar to Luczyński $\mathrm{W}$ et al. ${ }^{[171]}$ Other reticulocytes parameters generated by $\mathrm{Advia}^{\mathrm{R}} 2120 \mathrm{i}$ guided us in differential diagnosis of IDA, thalassemia, vitamin B12 deficiency and CKD. Our results of IRF were statistically significant to distinguish IDA and thalassemia ( $\mathrm{p}$ value $<0.05$ ).

$\mathrm{CHr}$ found to be more significant parameter than $\mathrm{MCV}$, reticulocyte\% and IRF in the diagnosis of IDA. Our results $\mathrm{CHr}$ as first parameter for monitoring response to intravenous iron therapy in IDA were in concordance with Buttarello $\mathrm{M}$ et $\mathrm{a}^{\left[{ }^{178]} \mathrm{CHr}\right.}$ was decreased in IDA, $\mathrm{CKD}$ and thalassemia major group as compared to control and increased in vitamin B12 deficiency group and these results were similar to C. Ceylan. ${ }^{[181]}$ The vitamin B12 deficiency group had significantly increased $\mathrm{MCVr}$ value as compared to control and other diseased group ( $\mathrm{p}$ value $<0.05)$ indicating its utility to diagnose megaloblastic anemia more precisely. Among microcytic anemias, only IRF and reticulocyte $\%$ are significant parameters between IDA and thalassemia major ( $\mathrm{p}$ value $<0.05$ ) so can be utilized to distinguish them. $\mathrm{CH} / \mathrm{CHr}$ ratio was maximally increased in IDA, but not as significant with thalassemia ( $\mathrm{p}$ value $>.05$ ). Other ratios like $\mathrm{MCVr} / \mathrm{MCV}$ and $\mathrm{CHCMr} /$ CHCM were also not as significant to compare IDA and thalassemia ( $\mathrm{p}$ value $>0.05$ ).

Manual differential counting is considered as the gold standard for the accurate identification of cells in the peripheral blood, ${ }^{[184]}$ however it is labor and time-intensive. [181,182] Therefore, CBCs and WBC differentials conducted using ACCs has replaced the traditional manual differential count method for the initial screening and detection of hematologic abnormalities in most laboratories.

\section{Conclusion}

Results of NRBC, FRCs by automated Advia ${ }^{R} 2120 \mathrm{i}$ were in excellent correlation with microscopic NRBC and schistocytes counts respectively. As our study has few such relevant cases, therefore additional studies with larger patients group are required for validation of clinical applications. IRF and reticulocyte $\%$ showed significant value to distinguish IDA and thalassemia major. $\mathrm{CHr}$ and $\mathrm{MCVr}$ are useful parameter for diagnosis of IDA/ thalassemia and vitamin B12 deficiency respectively with control groups. $\mathrm{CHr}$ was the first parameter that was responded to iron therapy even before MCV and IRF thus 
representing their role as non-invasive, inexpensive and objective indicator of a patient's bone marrow response. Moreover, it should be remembered that despite the essential role of automation, microscopy of pathologic samples remains essential.

Informed Consent: A written consent in the language the patients understands was taken from all the subjects being enrolled after explaining the objectives and benefits of the study to them.

Ethical Clearance: The study was then undertaken after due approval of the hospital ethics committee.

Funding Resources: No funding was obtained from any external source.

\section{Bibliography}

1. Vierordt K. New method of quantitative microscopic analysis of the blood. Arch of physiol. 1852; 41: 356-60. [2]

2. Coulter WH. Means for counting particles suspended in a fluid. 1953; 10: 508-13. [7]

3. Lesesve, J Martin, M Banasiak, C Andre-Kerneis, E Bardet, V Lusina, D Kharbach, A Genevieve, F Lecompte. Schistocytes in disseminated intravascular coagulation. International Journal of Laboratory Hematology. 2014; 36: 439-443. [73]

4. Zini G, d'Onofrio G, Briggs C, et al. ICSH recommendations for identification, diagnostic value, and quantitation of schistocytes. Int J Lab Hematol. 2012; 34: 107-16. [168]

5. Yesmin MS, Sultana T, Roy CK, Rehman MQ, Ahmed ANN. Immature reticulocyte fraction as a predictor of bone marrow recovery in children with acute lymphoblastic leukemia on remission induction phase. Bangladesh Med Counc Bull. 2011; 37: 57-60. [80]

6. Advani SH, Giri NK. Acute lymphoblastic leukemia in childhood : treatment, results and prognostic factors. Indian journal cancer. 1989; 26: 180-8. [87]

7. Kabata J, Tichelli A, Gratwohl A, Speck B. Flow cytometric pattern of leucocyte recovery after therapy induced aplasia. Acta Hematol Pol. 1994; 25: 329-42. [81]

8. Briggs C, Bain BJ. Basic haematological techniques. Dacie and Lewis Practical Haematology. 2012; 11: 342-58. [131]

9. Mast AE, Blinder MA, Lu Q, et al. Clinical utility of the reticulocyte hemoglobin content in the diagnosis of iron deficiency. Blood. 2002; 99: 1489-1491. [138]
10. Khusun H, Yip R, Schultink W, Dillon DH. World Health Organization hemoglobin cut-off points for the detection of anemia are valid for an Indonesian population. J Nutr. 1999;129:1669-74.

11. Zakai NA, French B, Arnold AM, Newman AB, Fried LF, Robbins J, Chaves P, Cushman M. Hemoglobin decline, function, and mortality in the elderly: the cardiovascular health study. Am J Hematol. 2013;88:5-9.

12. Gulati G, Behling E, Kocher W, Schwarting R. An evaluation of the performance of Sysmex XE-2100 in enumerating nucleated red cells in peripheral blood. Arch Pathol Lab Med. 2007; 131: 1077-83. [166]

13. Cui W, Wu W, Wang $\mathrm{X}$, et al. Development of the personalized criteria for microscopic review following four different series of hematology analyzer in a Chinese large scale hospital. Chin Med J. 2010; 123: 3231-7. [167]

14. J-F Lesesve, V Asnafi, F Braun, G Zini. Fragmented red blood cells automated measurement is a useful parameter to exclude schistocytes on the blood film. International Journal of Laboratory Hematology. 2012; 34: 566-76. [169]

15. Jean-Francois Lesesve, Amandine Daigney, Sylvain Henry, Elodie Speyer. Fragmented red cells reference range (Sysmex XN(®) automated blood cell counter). Annales de Biologie Clinique. 2015; 73: 547-56. [170]

16. Łuczyński W, Ratomski K, Wysocka J , KrawczukRybak M , Jankiewicz J. Immature reticulocyte fraction (IRF) - an universal markerof hemopoiesis in children with cancer? Eur J Haematol. 1994; 53: 293-7. [171]

17. Buttarello M, Temporin V, Ceravolo R, Farina G, Bulian P. The new reticulocyte parameter (Ret-y) of the Sysmex $\mathrm{XE} 2100$. Its use in the diagnosis and monitoring of post treatment sideropenic anemia. Am J Clin Pathol. 2004; 121: 489-95. [178]

18. C. Ceylan, M. Miskiog, H. C. Olak, B. Kilic, E. O. Zdemir. Evaluation of reticulocyte parameters in iron deficiency, vitamin b12 deficiency and b-thalassemia patients. Int J Lab Hematol. 2007; 29: 327-334. [181]

19. McClatchey KD. Clinical laboratory medicine. Philadelphia Lippincott Willimas and Wilkins. 2002; 8: 609-20. [184]

20. d'Onofrio G, Chirillo R, Zini G, Caenaro G, Tommasi M, Micciulli G. Simultaneous measurement of reticulocyte and red cell indices in healthy subjects and patients with microcytic and microcytic anemia. Blood. 1995; 85: 81823. $[182]$

*Corresponding author:

Dr. Gahlot Gaurav PS, Associate Professor, Dept of Lab \& Mol Med, Army Hospital (Research \& Referral) Delhi, India

Email: gpsinghgahlot@gmail.com

Financial or other Competing Interests: None. 